\title{
KEABSAHAN KUASA UNTUK MENANDATANGANI AKTA OLEH LEMBAGA PEMBIAYAAN JAMINAN FIDUSIA SUATU KAJIAN PERATURAN PEMERINTAH NOMOR 21 TAHUN 2015
}

\author{
Fandy Ahmad \\ Mahasiswa Program Studi Magister Hukum \\ Universitas Semarang
}

\begin{abstract}
ABSTRAK
Praktek pembuatan surat kuasa membebankan fidusia di bawah tangan oleh lembaga pembiayaan sangat marak terjadi dengan pertimbangan lembaga pembiayaan dapat sewaktu-waktu memasang akta jaminan fidusia apabila debitor terlihat menunjukkan gejala wanprestasi. Terkait dengan praktek pembuatan surat kuasa ini, Undang-Undang Jaminan Fidusia sama sekali tidak mengatur hal tersebut.

Permasalahan penelitian ini tentang bagaimana keabsahan surat kuasa membebankan fidusia di bawah tangan yang digunakan untuk menandatangani akta oleh lembaga pembiayaan dan akibat hukum terhadap sertifikat fidusia yang telah diperoleh lembaga pembiayaan, apabila pada saat pembuatan akta fidusianya didasari dengan surat kuasa membebankan fidusia di bawah tangan. Metode pendekatan yang digunakan adalah penelitian yuridis normatif yang merupakan penelitian deskriptif analitis. Jenis data yang digunakan adalah data sekunder. Metode pengumpulan data meliputi studi kepustakaan dan studi dokumentasi yang kemudian dianalisis secara kualitatif.

Kesimpulan dari penelitian ini, penggunaan surat kuasa membebankan fidusia di bawah tangan sebagai dasar pembuatan akta fidusia oleh lembaga pembiayaan selama ini tidak dapat dibenarkan menurut hukum. Walapun Undang-Undang Jaminan Fidusia tidak mengaturnya, hal ini bukan berarti penggunaan surat kuasa membebankan fidusia di bawah tangan dapat dibenarkan. Akibat hukum yang timbul dari pembuatan akta fidusia berdasarkan surat kuasa di bawah tangan membawa konsekuensi dapat tidak diperolehnya hak-hak istimewa lembaga pembiayaan selaku kreditor sebagaimana dijanjikan oleh undang-undang.
\end{abstract}

Kata Kunci: keabsahan, surat kuasa, fidusia 


\begin{abstract}
The practice of making an illegal power of attorney charging a fiduciary made by a financial institution is very prevalent with the consideration that the financial institution may at any time install a fiduciary guarantee certificate if the debtor appears to do default. The practice of making this power of attorney, the Fiduciary Guarantee Law does not regulate this matter at all.

The problem of this research is how the validity of the power of attorney imposes fiduciary illegally (underhand made) that is used to sign deed by the financing institution and the legal consequences of the fiduciary certificate obtained by the financial institution, in case that at the time of making the fiduciary deed based on the power of attorney to charge underhand fiduciary. The approach method used was normative juridical research, descriptive analytical research. The type of data used was secondary data. Data collection methods include literature studies and documentation studies which were then analyzed qualitatively.

The conclusion of this study, the use of a power of attorney to charge fiduciaries under the hands as the basis for making fiduciary deeds by financial institutions so far cannot be justified according to law. Even though the Fiduciary Guarantee Law does not regulate it, this does not mean that the use of a power of attorney to impose fiduciary under the hands can be justified. The legal consequences arising from the making of a fiduciary deed based on a power of attorney under the hands of the consequences of not being able to obtain the privileges of the financial institution as a creditor as mentioned by law.
\end{abstract}

Keywords: validity, power of attorney, fiduciary 


\section{PENDAHULUAN}

Dalam rangka memberikan payung hukum atas pelaksanaan pendaftaran jaminan fidusia secara elektronik (online) yang dilakukan oleh Kemenkumham, pemerintah telah menerbitkan Peraturan Pemerintah Nomor 21 Tahun 2015 tentang Tata Cara Pendaftaran Jaminan Fidusia dan Biaya Pembuatan Akta Jaminan Fidusia. Pembentukan sistem ini merupakan wujud usaha pemerintah untuk menegakkan isi dari Pasal 14 ayat (1) UUJF, yang menyebutkan bahwa kantor pendaftaran fidusia menerbitkan dan menyerahkan kepada penerima fidusia, sertifikat jaminan fidusia pada tanggal yang sama dengan tanggal penerimaan permohonan pendaftaran. Pendaftaran jaminan fidusia secara elektronik ini bertujuan agar seluruh pendaftaran jaminan fidusia dapat terdata secara nasional dalam database sehingga asas publisitas semakin meningkat.

Asas publisitas merupakan salah satu ciri jaminan hutang modern dengan tujuan semakin terpublikasinya suatu jaminan hutang, maka kreditur atau khalayak ramai dapat mengetahuinya atau punya akses untuk mengetahui informasiinformasi penting di sekitar jaminan hutang tersebut, sehingga diharapkan agar pihak debitur tidak dapat mengibuli kreditur atau calon kreditur dengan memfidusiakan sekali lagi atau bahkan menjual barang objek jaminan fidusia tanpa sepengetahuan kreditur asal. ${ }^{1}$

\footnotetext{
${ }^{1}$ Munir Fuady, Jaminan Fidusia : Cetakan Kedua Revisi (Bandung: Citra Aditya Bakti, 2003), halaman 30.
}

Namun demikian di sisi lain, ketika sistem pendaftaran jaminan fidusia diberlakukan secara online, ada kekhawatiran sistem tersebut menimbulkan permasalahan hukum. Sebagaimana diketahui, saat ini banyak lembaga pembiayaan (finance) menyelenggarakan pembiayaan bagi konsumen (consumer finance), sewa guna usaha (leasing), anjak piutang (factoring) yang pada umumnya menggunakan tata cara perjanjian yang mengikutkan adanya jaminan fidusia bagi objek benda jaminan fidusia.

Prakteknya, lembaga pembiayaan menyediakan barang bergerak yang diminta konsumen (semisal motor atau mesin industri) kemudian diatasnamakan konsumen sebagai debitur (penerima kredit/ pinjaman). Konsekuensinya debitur menyerahkan kepada kreditur (pemberi kredit) secara fidusia. Artinya, debitur sebagai pemilik atas nama barang menjadi pemberi fidusia kepada kreditur yang dalam posisi sebagai penerima fidusia. Praktek sederhana dalam jaminan fidusia adalah debitur/pihak yang punya barang mengajukan pembiayaan kepada kreditor, lalu kedua belah sama-sama sepakat mengunakan jaminan fidusia terhadap benda milik debitor.

Menurut

Peraturan

Pemerintah Nomor 21 Tahun 2015 tentang Tata Cara Pendaftaran Jaminan Fidusia dan Biaya Pembuatan Akta Jaminan Fidusia, ada kewajiban bagi para notaris untuk mendaftarkan jaminan fidusia (bukan perubahannya) 
secara online dalam waktu 30 hari setelah akta jaminan fidusia ditandatangani. Ketentuan ini pada prinsipnya demi menjamin kepastian hukum.

Akibat berlakunya jangka waktu pendaftaran fidusia dalam Peraturan Pemerintah Nomor 21 Tahun 2015 ini, timbul masalah terhadap fidusia-fidusia yang belum sempat didaftarkan (pending karena berbagai hal). Apakah akta jaminan fidusia yang tanggal pendaftarannya terlampaui (expired) masih dapat didaftarkan. Jika tidak dapat didaftarkan, bagaimana dengan kedudukan akta jaminan fidusia tersebut, yang notabene sudah terlanjur dibuat dan masih tetap berlaku bagi para pihak.

Beberapa permasalahan tersebut muncul karena prosedur baru pendaftaran jaminan fidusia secara online sebagaimana diatur dalam Peraturan Pemerintah Nomor 21 Tahun 2015 tidak memberikan jalan keluar atas masalah ini. Peraturan Pemerintah tersebut dalam hal ini tidak menyebutkan, apabila tanggal pendaftarannya terlampaui (expired), akta jaminan fidusia secara hukum menjadi tidak berlaku. Sebagai solusinya, apakah para pihak harus menandatangani akta penjaminan kembali, tidak ada penjelasannya.

Dalam praktek lembaga pembiayaan, untuk mengatasi hal ini biasanya dibuatkan Surat Kuasa Membebankan Fidusia (SKMF) yang dibuat secara sepihak (baku) oleh lembaga pembiayaan. SKMF adalah kuasa yang diberikan oleh debitor kepada kreditor untuk membebankan/membuat akta fidusia dihadapan notaris. Dengan adanya kuasa tersebut, kreditor dapat membebankan/membuat akta fidusia sewaktu-waktu tanpa perlu lagi bantuan dari debitor.

Terkait hal ini, pertanyaan yang muncul adalah apakah bentuk SKMF yang dibuat secara sepihak (baku) dan dibawah tangan oleh lembaga pembiayaan tersebut, dapat dijadikan dasar untuk melakukan perbuatan hukum menghadap notaris pada saat pembuatan akta jaminan fidusia. $\mathrm{Hal}$ ini mengingat, sistem pendaftaran fidusia secara online yang diatur dalam Peraturan Pemerintah Nomor 21 Tahun 2015 tidak mengatur masalah tersebut.

Meskipun pendaftaran fidusia dilakukan dengan menggunakan SKMF di bawah tangan oleh lembaga pembiayaan selaku penerima fidusia (berbekal kuasa pendaftaran yang diberikan dalam akta jaminan fidusia), namun apakah ada jaminan dari instansi berwenang bahwa cara tersebut memberikan legalitas yang sama, seperti halnya dalam hak tanggungan dikenal Surat Kuasa Membebankan Hak Tanggungan (SKMHT). Dengan kata lain, apakah pembuatan akta fidusia bisa dibuat berdasarkan SKMF seperti halnya dalam hak tanggungan yang dibuat berdasarkan SKMHT.

$\mathrm{Hal}$ ini mengingat, disatu sisi praktek pembuatan SKMF di lingkungan lembaga pembiayaan sangat marak terjadi dengan pertimbangan bahwa lembaga pembiayaan dapat sewaktu-waktu memasang akta jaminan fidusia apabila debitor terlihat menunjukkan gejala wanprestasi. Namun di sisi yang lain, terkait dengan praktek pembuatan SKMF di bawah tangan ini, Peraturan Pemerintah Nomor 21 Tahun 2015 yang mengatur tentang tata cara pendaftaran jaminan fidusia sama 
sekali tidak mengatur hal tersebut. Pertanyaan yang relevan diajukan di sini adalah bagaimana dengan keabsahan SKMF yang dibuat secara sepihak (baku) dan di bawah tangan oleh lembaga pembiayaan tersebut menurut hukum positif di Indonesia.

Berdasarkan uraian latar belakang sebagaimana dipaparkan di atas, maka perlu dilakukan kajian terkait dengan permasalahan keabsahan surat kuasa membebankan fidusia yang dibuat secara baku dan di bawah tangan oleh lembaga pembiayaan, yang digunakan untuk melakukan perbuatan hukum menghadap notaris pada saat pembuatan akta jaminan fidusia.

\section{PERUMUSAN MASALAH}

Berpijak dari latar belakang penelitian sebagaimana telah diuraikan di atas, dalam penelitian ini pokok permasalahan yang akan dikaji lebih lanjut dirumuskan sebagai berikut:

1. Bagaimana keabsahan surat kuasa membebankan fidusia di bawah tangan yang digunakan untuk menandatangani akta oleh lembaga pembiayaan berdasar Peraturan Pemerintah Nomor 21 Tahun 2015?

2. Bagaimanakah akibat hukum terhadap sertifikat fidusia yang telah diperoleh lembaga pembiayaan, apabila pada saat pembuatan akta fidusianya didasari dengan surat kuasa membebankan fidusia di bawah tangan?

III. PEMBAHASAN

A. Keabsahan Surat Kuasa Membebankan Fidusia Di Bawah Tangan yang Digunakan untuk

$\begin{array}{lr}\begin{array}{l}\text { Menandatangani } \\ \text { Lembaga }\end{array} & \begin{array}{c}\text { Akta oleh } \\ \text { Pembiayaan }\end{array} \\ \text { Berdasar r r r } & \text { Peraturan } \\ \text { Pemerintah Nomor 21 Tahun } & \\ 2015 & \end{array}$

Terkait dengan permasalahan pertama dalam penelitian ini, yaitu tentang keabsahan surat kuasa membebankan fidusia di bawah tangan yang digunakan untuk menandatangani akta oleh lembaga pembiayaan, peneliti akan menguraikan perkara tentang pembatalan Akta Jaminan Fidusia Nomor 77 tanggal 2 Juli 2015 dengan pemberi fidusia Royke Erick dan penerima fidusia PT. Mitsui Leasing Capital Indonesia sebagaimana dimuat dalam Putusan Pengadilan Tinggi Bandung Nomor 87/PDT/2018/PT.BDG.

Putusan Pengadilan Tinggi Bandung Nomor : 87/PDT/2018/ PT.BDG adalah perkara perdata tentang pembatalan akta jaminan fidusia, dengan obyek jaminan fidusia kendaraan roda empat, merk Toyota, tipe New Avanza Veloz $1.5 \mathrm{~A} / \mathrm{T}$. Jika dikaji secara teliti, dalam putusan tersebut terlihat adanya praktek pembuatan surat kuasa membebankan fidusia yang dibuat secara baku dan di bawah tangan oleh perusahaan pembiayaan PT. Mitsui Leasing Capital Indonesia Cabang Bandung.

Duduk perkara ini dilatarbelakangi oleh adanya hubungan hukum jual beli mobil Toyota Avanza Veloz 1.5 AT, antara Antonius Hanung selaku penjual dengan Royke Erick selaku pembeli, demikian itu 
dibuktikan dengan adanya kwitansi tertanggal 29 Mei 2014, yang isinya menyatakan bahwa Antonius Hanung telah menerima uang sebesar Rp. 150.000.000.- (seratus lima puluh juta rupiah) dari Royke Erick untuk pembelian 1 (satu) unit Toyota Avanza Veloz 1.5 A/T Minibus, Tahun 2013, dengan No. Rangka MHKM 1CB4JDK025807 dan No. Mesin DDX7631.

Sehubungan dengan keinginan Royke Erick untuk membeli mobil Toyota Avanza Veloz 1.5 AT tersebut, maka Royke Erick mengajukan permohonan pembiayaan kepada PT. Mitsui Leasing Capital Indonesia Cabang Bandung. Permohonan tersebut kemudian disetujui oleh PT. Mitsui Leasing Capital Indonesia Cabang Bandung dengan ditandatanganinya Perjanjian Pembiayaan Konsumen No.231410575 tertanggal 30 Juni 2014 yang ditandatangani oleh Royke Erick dan PT. Mitsui Leasing Capital Indonesia Cabang Bandung.

Dalam Perjanjian

Pembiayaan Konsumen No. 231410575 tertanggal 30 Juni 2014 tersebut, telah disepakati atas utang Royke Erick yaitu utang pokok, bunga dan biaya lainnya sebesar Rp. 142.240.000,- (seratus empat puluh dua juta dua ratus empat puluh ribu rupiah) yang akan dibayar dalam 36 (tiga puluh enam) angsuran dari tanggal 30 Juni 2014 sampai dengan tanggal 30 Mei 2017, dengan angsuran sebesar Rp. 4.090.000,- (empat juta sembilan puluh ribu rupiah).
Setelah

ditandatanganinya perjanjian pembiayaan tersebut, Royke Erick memberikan surat kuasa membebankan fidusia kepada PT. Mitsui Leasing Capital Indonesia Cabang Bandung sebagaimana terbukti dalam Surat Kuasa Penjaminan tertanggal 30 Juni 2014, di dalam surat tersebut Royke Erick memberikan kuasa kepada PT. Mitsui Leasing Capital Indonesia Cabang Bandung untuk dapat melakukan pengurusan dan melaksanakan serta menjaminkan secara fidusia mobil Toyota Avanza Veloz 1.5 AT tersebut.

Berdasarkan Surat Kuasa Penjaminan tersebut, selanjutnya PT. Mitsui Leasing Capital Indonesia Cabang Bandung meminta kepada Notaris Novitas Kusumaswita, berkedudukan di Kabupaten Bandung, Jawa Barat untuk dibuatkan akta jaminan fidusia dan pendaftaran jaminan fiducia sebagaimana terbukti dalam Surat Permohonan PT. Mitsui Leasing Capital Indonesia Cabang Bandung tertanggal 30 Juni 2014. Berdasarkan surat permohonan tersebut, Notaris Novitas Kusumaswita kemudian menerbitkan Akta Jaminan Fiducia No. 77 tertanggal 2 Juli 2014 setelah terlebih dahulu diteliti seluruh dokumen-dokumen terkait dengan Perjanjian Pembiayaan Konsumen No.231410575 tertanggal 30 Juni 2014 yang ditandatangani oleh Royke Erick dan PT. Mitsui Leasing Capital Indonesia Cabang Bandung. Dengan telah 
dibuatkannya akta fidusia dan diajukannya permohonan pendaftaran kepada Menteri Hukum dan Hak Asasi Manusia Republik Indonesia, selanjutnya Menteri Hukum dan Hak Asasi Manusia Republik Indonesia mengeluarkan Sertifikat Jaminan Fidusia Nomor W11.01336913.AH.05.01

Tahun 2014 tanggal 10 Juli 2014.

Berdasarkan uraian penjelasan tersebut di atas, diketahui bahwa Royke Erick dan PT. Mitsui Leasing Capital Indonesia Cabang Bandung telah terikat dalam suatu Perjanjian Pembiayaan Konsumen No. 231410575 tertanggal 30 Juni 2014, dengan pokok utang sebesar Rp. 120.912.000,- (seratus dua puluh juta sembilan ratus dua belas ribu rupiah), dengan obyek jaminan 1 (satu) unit kendaraan mobil Toyota Avanza Veloz 1.5 A $\mathrm{T}$, warna/tahun silver metalik/2013, nomor rangka MHKMICB43DK025807 dan nomor mesin DDX7631 BPKB. Selanjutnya

Perjanjian Pembiayaan Konsumen No. 231410575 tertanggal 30 Juni 2014 tersebut, maka dibuatlah Akta Jaminan Fidusia No. 77 tanggal 2 Juli 2014 yang dibuat dihadapan Novita Kusumaswinta Notaris di Kabupaten Bandung, Jawa Barat, yang kemudian dilanjutkan dengan pembuatan Sertifikat Jaminan Fidusia No. W11.01336913.AH.05.01

Tahun 2014 tanggal 10 Juni 2014, yang diterbitkan oleh Kantor Wilayah Jawa Barat Kantor Pendaftaran Jaminan
Fidusia Kementerian Hukum dan Hak Asasi Manusia Republik Indonesia.

Berdasarkan uraian singkat tentang praktek pembuatan surat kuasa membebankan fidusia, yang dibuat secara sepihak dan dilakukan di bawah tangan oleh PT. Mitsui Leasing Capital Indonesia Cabang Bandung, sebagaimana dimuat dalam Putusan Pengadilan Tinggi Bandung Nomor : 87/PDT/2018/PT.BDG tersebut di atas, selanjutnya akan dianalisis permasalahan pertama dalam penelitian ini tentang keabsahan surat kuasa membebankan fidusia di bawah tangan yang digunakan untuk menandatangani akta oleh lembaga pembiayaan.

Sebagaimana telah peneliti jelaskan di awal penelitian ini, bahwa Putusan Pengadilan Tinggi Bandung Nomor : 87/PDT/2018/ PT.BDG adalah putusan dalam perkara perdata yang salah satu amar putusannya menyatakan Sertifikat Jaminan Fidusia No. W11.01336913.AH.05.01

Tahun 2014 tanggal 10 Juni 2014 tidak sah dan tidak mempunyai kekuatan hukum. Berdasar amar Putusan Pengadilan Tinggi Bandung Nomor : 87/PDT/2018/PT.BDG tersebut, diketahui bahwa akta jaminan fidusia dan sertifikat jaminan fidusia yang dibuat berdasarkan surat kuasa membebankan fidusia di bawah tangan, ternyata tidak memiliki kekuatan hukum apapun. Faktanya, Akta Jaminan Fidusia Nomor 77 tanggal 2 Juli 2015, yang dibuat oleh Notaris Novitas Kusumaswita dan 
Sertifikat Jaminan Fidusia No. W11.01336913.AH.05.01

Tahun 2014 tanggal 10 Juni 2014, yang diterbitkan oleh Kantor Wilayah Jawa Barat Kantor Pendaftaran Jaminan Fidusia Kementerian Hukum dan Hak Asasi Manusia Republik Indonesia, oleh Pengadilan Tinggi Bandung dinyatakan tidak sah dan tidak mempunyai kekuatan hukum.

Digunakannya suatu kuasa adalah dimaksudkan agar penerima kuasa menjadi berwenang melakukan perbuatan hukum untuk dan atas nama pemberi kuasa. Kuasa dapat diberikan melalui perbuatan hukum sepihak ${ }^{2}$, atau perbuatan hukum dalam bentuk perjanjian seperti lastgeving. Kuasa yang diberikan secara sepihak hanya menimbulkan wewenang bagi penerima kuasa, namun tidak menimbulkan kewajiban bagi penerima kuasa untuk melaksanakan kuasa itu. Sementara itu apabila kuasa itu diberikan melalui perbuatan hukum perjanjian seperti lastgeving, maka kuasa itu menimbulkan kewajiban bagi penerima kuasa untuk melaksanakan kuasa. ${ }^{3}$

${ }^{2}$ Kuasa (volmacht) yang diberikan melalui perbuatan hukum sepihak disebut machtiging yaitu pernyataan kehendak oleh orang yang diwakili yang tertuju kepada pemberian "macht' (kuasa). Hartono Soerjopratiknjo, Perwakilan Berdasarkan Kehendak (Yogyakarta: Seksi Notariat, Fakultas Hukum, Universitas Gadjah Mada, 1982), halaman 63.

3 Rachmad Setiawan, Hukum Perwakilan dan Kuasa, Suatu Perbandingan Hukum Indonesia dan Hukum Belanda Saat Ini (Jakarta: Tatanusa, 2005), halaman 20. $\begin{array}{rrr}\text { Dilihat dari } & \text { perkara } \\ \text { pembatalan Akta Jaminan }\end{array}$ Fidusia Nomor 77 tanggal 2 Juli 2015 dengan pemberi fidusia Royke Erick dan penerima fidusia PT. Mitsui Leasing Capital Indonesia sebagaimana dimuat dalam Putusan Pengadilan Tinggi Bandung Nomor: 87/PDT/ 2018/PT.BDG, dapat diketahui bahwa surat kuasa membebankan fidusia tersebut dibuat di bawah tangan dan dituangkan dalam bentuk perjanjian, sehingga dapat disimpulkan bahwa surat kuasa membebankan fidusia tersebut berbentuk lastgeving. Ketentuan mengenai lastgeving secara jelas telah diatur dalam Buku III Bab XVI mulai dari Pasal 1792 sampai dengan Pasal 1819 KUHPerdata, ${ }^{4}$ sedangkan ketentuan mengenai dapat atau tidaknya dan bagaimana bentuk seharusnya surat kuasa membebankan fidusia dibuat, Undang-Undang Jaminan Fidusia $^{5}$ maupun Peraturan Pemerintah Nomor 21 Tahun 2015 sebagai peraturan pelaksanaannya sama sekali tidak mengaturnya.

Artinya, dalam UndangUndang Jaminan Fidusia hanya mengatur bahwa pembebanan/pembuatan akta fidusia wajib dibuat dengan akta otentik. Namun tidak pernah melarang atau mengatur

pembebanan/pembuatan akta

4 Herlien Budiono, Kumpulan Tulisan Hukum Perdata: Di Bidang Kenotariatan (Buku 1) (Jakarta: Citra Aditya, 2007), halaman 53.

5 Undang-Undang Republik Indonesia Nomor 42 Tahun 1999 tentang Jaminan Fidusia, Pasal 5 ayat (1). 
fidusia dilakukan melalui kuasa. Dengan adanya kekosongan hukum dalam Undang-Undang Jaminan Fidusia inilah yang telah menyebabkan praktek mengadopsi ketentuan lastgeving dalam Buku III KUHPerdata untuk memenuhi inisiatifnya dalam pembuatan surat kuasa membebankan fidusia. Akibatnya, dalam praktek di lingkungan lembaga pembiayaan, prinsip pemberian kuasa itu bebas bentuk dan dapat dilakukan untuk semua perbuatan hukum, sehingga dapat dijadikan dasar pembenar dalam pembuatan surat kuasa membebankan fidusia di bawah tangan.

Pada prinsipnya hampir semua tindakan hukum dapat dikuasakan kepada orang lain untuk melakukannya, kecuali sesuatu yang erat hubungannya dengan pribadi seseorang, misalnya, membuat surat wasiat/testament dan pengakuan anak. Adanya asas umum dalam hukum perdata, dimana selama tidak diatur maka itu boleh/dapat dilakukan juga telah mendukung pendapat di lingkungan lembaga pembiayaan dalam praktek pembuatan surat kuasa membebankan fidusia di bawah tangan. Bahkan, doktrin juga mengajarkan apabila suatu perbuatan hukum diwajibkan bentuk tertentu, bentuk kuasanya tetap bebas sepanjang undang-undang untuk kuasa itu tidak menentukan lain. ${ }^{6}$

6 J. Satrio, Hukum Jaminan, Hak-hak Jaminan Kebendaan (Bandung: PT. Citra Aditya Bhakti, 2001), halaman 168. Lihat Juga Rachmad Setiawan, op.cit., halaman 28.

\begin{abstract}
Berdasarkan pertimbangan-pertimbangan tersebut, kiranya logis apabila praktek penggunaan surat kuasa membebankan fidusia di bawah tangan dapat dilakukan dalam pembebanan/pembuatan akta fidusia di lingkungan lembaga pembiayaan, mengingat tidak ada satupun ketentuan dalam UndangUndang Jaminan Fidusia maupun Peraturan Pemerintah Nomor 21 Tahun 2015 sebagai peraturan pelaksanaannya yang melarang mengenai pembuatan surat kuasa membebankan fidusia di bawah tangan. Namun, terkait dengan keabsahan dari surat kuasa membebankan fidusia tersebut, sebagaimana telah peneliti jadikan sebagai pokok
\end{abstract} permasalahan dalam penelitian ini, maka patut untuk dipertimbangkan terlebih dahulu, bahwa jaminan fidusia adalah bagian dari jaminan kebendaan yang merupakan sub sistem dari hukum benda yang meletakan asas tertutup dan memaksa (dwingendrecht). Hukum benda mempunyai sifat tertutup maksudnya ialah bahwa hak-hak benda hanya dapat diatur dengan undangundang. Selain itu hukum benda mengandung sifat memaksa, maksudnya ialah bahwa ketentuan tentang hukum benda wajib dipatuhi dan tak dapat disimpangi. ${ }^{7}$

Dalam konteks ini, tentu sangat bertolak belakang dengan lastgeving yang merupakan sub sistem dalam hukum kontrak yang meletakan

7 Mariam Darus Badrulzaman, Sistem Hukum Benda Nasional, (Bandung: Alumni,1994) halaman 4. 
asas terbuka dan pelengkap (aanvullendrecht). Artinya, ketentuan dalam Buku III KUHPerdata bersifat menambah atau mengatur atau melengkapi, dengan sifat yang demikian memiliki konsekuensi bahwa pihak-pihak yang membuat perjanjian memiliki kebebasan untuk menyimpangi ketentuan-ketentuan yang terdapat dalam Buku III tersebut.

Buku III KUHPerdata juga menganut sifat terbuka yang bermakna orang bebas mengadakan perjanjian jenis baru selain yang dikenal/diatur dalam Buku III tersebut. ${ }^{8}$ Berdasarkan alasan tersebut, maka semestinya ketentuan lastgeving tidak dapat diadopsi begitu saja untuk mengisi ketiadaan pengaturan dalam sistem hukum benda. Hal ini mengingat antara sistem hukum yang berbeda sering terdapat perbedaan-perbedaan. Ketentuan yang diketemukan dalam sistem yang satu tidak selalu dapat diterapkan begitu saja ke dalam sistem yang lain. ${ }^{9}$

Prinsip bahwa ketentuan Buku III KUHPerdata tidak dapat diterapkan begitu saja dalam sistem hukum benda ini juga dapat dilihat pada keberadaan perjanjian kebendaan. Dimana ketentuan perjanjian obligatoir dalam Buku III KUHPerdata tidak

8 Ridwan Khairandy, Hukum Kontrak Indonesia Dalam Perspektif Perbandingan (Yogyakarta:UII Press, 2013), halaman 16 17.

9 Sudikno Mertokusumo, Penemuan Hukum Sebuah Pengantar, Edisi Revisi (Yogyakarta:Cahaya Atma Pustaka, 2004), halaman 26. semua berlaku/dapat

digunakan dalam perjanjian kebendaan. Kata perjanjian dalam perjanjian kebendaan, hanya dimaksudkan untuk menunjukan bahwa perjanjian kebendaan didasarkan atas kata sepakat.

Artinya, jangan disalah artikan bahwa perjanjian kebendaan termasuk perjanjian dalam Buku III KUHPerdata. Perjanjian kebendaan merupakan perjanjian yang mengubah, mengalihkan maupun menimbulkan hak kebendaan. Selain itu perjanjian kebendaan tidak menimbulkan perikatanperikatan seperti perjanjian obligatoir. Sehingga disini ketentuan perjanjian dalam Buku III KUHPerdata tidak berlaku terhadap perjanjian kebendaan. ${ }^{10}$ Oleh sebab itu, untuk mengetahui sah atau tidaknya surat kuasa membebankan fidusia sebagai dasar pembebanan/pembuatan akta fidusia oleh lembaga pembiayaan, maka perlu untuk menemukan hukumnya, karena seseorang tidak dapat begitu saja mengatakan sah, atau tidak sah hanya dengan dasar tidak ada ketentuan yang mengaturnya.

Dalam hal terjadi kekosongan hukum, ilmu hukum telah menyediakan beberapa metode yang dapat digunakan untuk menemukan hukum dalam keadaan mana undang-undang tidak mengaturnya salah satunya adalah metode penemuan

10 J. Satrio, Hukum Perikatan, Perikatan yang lahir dari Perjanjian Buku I, Cetakan II (Bandung: PT Citra Aditya Bhakti, 2001), halaman 57-58. 
hukum (analogi), yaitu dengan menganalogikan fidusia dengan jaminan kebendaan lainnya dalam suatu sistem hukum jaminan kebendaan. Melihat pada hipotik dan hak tanggungan dapat diketahui bahwa apabila memang diperlukan, penggunaan kuasa dapat diterapkan dalam pembebanan objek jaminan (Pasal 1171 KUHPerdata dan Pasal 15 Undang-Undang Hak Tanggungan).

Berdasarkan hal tersebut, maka penggunaan surat kuasa membebankan fidusia untuk pembuatan akta fidusia juga dapat dibenarkan menurut sistem hukum jaminan, tentu dengan syarat bahwa bentuknya juga harus mengikuti bentuk kuasa yang dikenal dan memang diatur dalam hukum jaminan kebendaan, yaitu harus dituangkan dalam bentuk akta otentik. Penyimpangan terhadap bentuk dari surat kuasa tersebut, tentu akan mengakibatkan kebatalan terhadap surat kuasa membebankan fidusia tersebut. Artinya, surat kuasa membebankan fidusia di bawah tangan yang digunakan untuk menandatangani akta oleh lembaga pembiayaan yang terjadi selama ini adalah tidak sah, karena tidak dibuat dalam bentuk akta otentik.

Ketentuan perbuatan hukum yang dapat melahirkan kuasa (lastgeving) dalam Buku III KUHPerdata tidak semua dapat diberlakukan/digunakan untuk pemberian kuasa dalam sistem hukum jaminan kebendaan. Penggunaan kata kuasa dalam hukum jaminan kebendaan hanya dimaksudkan untuk menunjukan bahwa dalam kuasa tersebut terdapat kewenangan. Hal ini tidak berarti bahwa kuasa dalam hukum jaminan kebendaan adalah kuasa yang termasuk dalam dalam Buku III KUHPerdata.

Berdasarkan hasil pembahasan tersebut di atas, maka penggunaan surat kuasa membebankan fidusia di bawah tangan sebagai dasar pembuatan akta fidusia oleh lembaga pembiayaan selama ini tidak dapat dibenarkan menurut hukum jaminan nasional. Walapun UndangUndang Jaminan Fidusia dan Peraturan Pemerintah Nomor 21 Tahun 2015 tidak mengaturnya, hal ini bukan berarti penggunaan surat kuasa membebankan fidusia di bawah tangan dapat dibenarkan.

Secara sistemik hukum jaminan telah meletakan fidusia sebagai bagian dari sistem hukum jaminan kebendaan yang menganut asas tertutup dan memaksa. Oleh karena itu, ketiadaan pengaturan mengenai surat kuasa membebankan fidusia dalam Undang-Undang Jaminan Fidusia dan Peraturan Pemerintah Nomor 21 Tahun 2015 tidak dapat begitu saja diisi oleh ketentuan perbuatan hukum yang dapat melahirkan kuasa (lastgeving) dalam Buku III KUHPerdata. Melainkan secara sistemik harusnya digunakan ketentuan hukum jaminan kebendaan yang lain untuk melengkapinya.

Undang-Undang Jaminan

Fidusia dan Peraturan Pemerintah Nomor 21 Tahun 2015 bukanlah sekedar 
kumpulan peraturanperaturan/norma-norma yang berdiri sendiri. Melainkan memiliki arti penting dalam kaitannya dengan peraturanperaturan hukum jaminan kebendaan secara keseluruhan yang dibangun di atas asasasas tertib hukum untuk membentuk suatu kesatuan dalam sistem hukum jaminan kebendaan.

B. Akibat Hukum terhadap Sertifikat Fidusia yang Telah Diperoleh Lembaga Pembiayaan, Apabila Pada Saat Pembuatan Akta Fidusianya Didasari dengan Surat Kuasa Membebankan Fidusia Di Bawah Tangan

Jika mengacu pada Putusan Pengadilan Tinggi Bandung Nomor
87/PDT/2018/PT.BDG, diketahui bahwa beberapa fase yang harus dilalui agar PT. Mitsui Leasing Capital Indonesia Cabang Bandung selaku lembaga pembiayaan (kreditor) dapat memperoleh sertifikat fidusia adalah sebagai berikut:

1. Pembuatan Perjanjian Pembiayaan Konsumen No.231410575 tertanggal 30 Juni 2014, antara PT. Mitsui Leasing Capital Indonesia Cabang Bandung selaku kreditor dengan Royke Erick selaku debitor;

2. Pembuatan Surat Kuasa Penjaminan tertanggal 30 Juni 2014, antara PT. Mitsui Leasing Capital Indonesia Cabang Bandung selaku kreditor dengan Royke Erick selaku debitor;
3. Pembuatan Surat Permohonan Pembuatan dan Pendaftaran Akta Fidusia tertanggal 30 Juni 2014, yang ditujukan kepada Novita Kusumaswita selaku Notaris;

4. Berdasarkan Surat Kuasa Penjaminan tertanggal 30 Juni 2014 dan Surat Permohonan Pembuatan dan Pendaftaran Akta Fidusia tertanggal 30 Juni 2014 yang dibuat oleh PT. Mitsui Leasing Capital Indonesia Cabang Bandung, Novita Kusumaswita selaku Notaris membuat Akta Jaminan Fidusia No. 77 tertanggal 2 Juli 2014 dan mendaftarakan akta jaminan fidusia tersebut ke Kementrian Hukum dan Hak Asasi Manusia Republik Indonesia pada tanggal 10 Juli 2014;

5. Kementrian Hukum dan Hak Asasi Manusia Republik Indonesia menerbitkan Sertifikat Jaminan Fidusia Nomor W11.01336913.AH.05.01

Tahun 2014 tertanggal 10 Juli 2014.

Berasarkan uraian penjelasan tersebut di atas, diketahui bahwa lembaga pembiayaan selaku kreditor tetap dapat memperoleh sertifikat fidusia, meskipun pembuatan akta fidusianya dilakukan melalui surat kuasa membebankan fidusia di bawah tangan. Hal ini sebenarnya juga didukung oleh faktor pemberlakuan pendaftaran fidusia melalui sistem elektronik (online system). Ketentuan ini 
dapat dilihat pada Peraturan Pemerintah Nomor 21 Tahun 2015 tentang Tata Cara Pendaftaran Jaminan Fidusia dan Biaya Pembuatan Akta Jaminan Fidusia jo Peraturan Menteri Hukum dan Hak Asasi Manusia Republik Indonesia Nomor 09 Tahun 2013 tentang Pemberlakuan Pendaftaran Jaminan Fidusia Secara Elektronik, Peraturan Menteri Hukum dan Hak Asasi Manusia Republik Indonesia Nomor 08 Tahun 2013 tentang Pendelegasian

Penandatanganan Sertifikat Jaminan Fidusia Secara Elektronik dan Peraturan Menteri Hukum dan Hak Asasi Manusia Republik Indonesia Nomor 10 Tahun 2013 tentang Tata Cara Pendaftaran Jaminan Fidusia Secara Elektronik.

Diberlakukannya

ketentuan-ketentuan tersebut, maka pendaftaran fidusia yang dulunya dilakukan secara manual di Kantor Pendaftaran Fidusia (KPF) telah beralih dengan menggunakan sistem pendaftaran jaminan fidusia secara online. Menurut Pasal 3 Peraturan Mentri Hukum dan Hak Asasi Manusia Nomor 9 Tahun 2013, menyatakan bahwa "Pendaftaran jaminan fidusia secara elektronik sebagaimana dimaksud dalam Pasal 2 dapat dilakukan melalui kios pelayanan pendaftaran jaminan fidusia secara eletronik diseluruh kantor pendaftaran fidusia". Kios pelayanan pendaftaran jaminan fidusia yang dimaksud tidak terdapat penjelasannya pada peraturan menteri tersebut. Selanjutnya pengertian kantor pendaftaran fidusia terdapat pada Pasal 1 ayat (5) Peraturan Menteri Nomor 10 Tahun 2013 menyatakan bahwa "kantor pendaftaran fidusia adalah kantor yang menerima permohonan pendaftaran jaminan fidusia secara elektronik". Pada pengertian ini pun tidak jelas kantor mana yang menerima permohonan pendaftaran jaminan fidusia secara elektronik.

Pada prakteknya pendaftaran jaminan fidusia secara elektronik atau online dilakukan di kantor notaris, karena hanya notaris yang memiliki username dan password untuk dapat mengakses menu layanan website www.ahu.go.id, sehingga dengan adanya kewenangan akses yang dimilikinya tersebut, notaris akan melakukan pendaftaran jaminan fidusia secara online dengan menginput data sesuai dengan akta pembebanan yang dibuatnya, untuk selanjutnya notaris sendiri jugalah yang akan mencetak sertifikat fidusia yang mengandung irah-irah "Demi Keadilan Berdasarkan Ketuhanan Yang Maha Esa".

Diberlakukannya

pendaftaran fidusia melalui sistem elektronik (online system) tersebut, dapat diketahui bahwa proses pelaksanaan pendaftaran objek jaminan fidusia saat ini menjadi lebih mudah dan cepat, karena dapat diakses secara online melalui satu pintu yaitu notaris. Oleh sebab itu, notaris yang berpandangan bahwa penggunaan surat kuasa membebankan fidusia di bawah tangan dapat diterapkan dalam 
pembebanan/pembuatan akta fidusia, tentu akan tetap memproses pendaftaran fidusia sampai kreditor memperoleh sertifikat fidusia.

Artinya, dapat dikatakan bahwa notaris juga berperan terhadap keberadaan surat kuasa membebankan fidusia di bawah tangan. Dengan tetap diperolehnya sertifikat fidusia oleh lembaga pembiayaan selaku kreditor yang melakukan pembuatan akta fidusia melalui surat kuasa membebankan fidusia di bawah tangan, telah membawa anggapan pada lembaga pembiayaan selaku kreditor penerima fidusia, bahwa mereka tetap merasa aman dan dilindungi hakhaknya sebagai kreditor yang istimewa dimata undangundang. Apabila debitor wanprestasi, lembaga pembiayaan selaku kreditor tetap dapat mengeksekusi secara langsung objek fidusia yang dijaminkan debitor dengan menunjukan sertifikat jaminan fidusia yang telah diperolehnya dari pendaftran secara online melalui notaris.

Berdasarkan uraian penjelasan tersebut, maka apakah dapat dikatakan bahwa lembaga pembiayaan selaku kreditor yang menggunakan surat kuasa membebankan fidusia di bawah tangan sebagai dasar pembuatan akta fidusia tetap mempunyai hakhak istimewa yang diberikan undang-undang. Jawabnya, secara teori tentu tidaklah demikian adanya.

Faktor penyebab akan sangat berperan untuk menentukan suatu akibat. Dilihat secara administratif, memang lembaga pembiayaan selaku kreditor telah memenuhi syarat untuk memperoleh sertifikat fidusia, yaitu dengan dibuatnya akta fidusia notariil (Pasal 5 ayat (1) UndangUndang Jaminan Fidusia dan didaftarkannya objek jaminan fiusia (Pasal 11 ayat (1) Undang-Undang Jaminan Fidusia), namun melihat dari perolehannya disini, terdapat suatu faktor penyebab yang tidak dapat dihilangkan, yaitu digunakannya surat kuasa membebankan fidusia di bawah tangan sebagai dasar pembuatan akta fidusia.

Berdasarkan

pembahasan tersebut di atas, maka akibat hukum yang timbul maupun diperoleh lembaga pembiayaan selaku kreditor dari pembuatan akta fidusia berdasarkan surat kuasa tersebut, akan bergantung pada keabsahan surat kuasa membebankan fidusia yang telah dibuat sebelumnya. Meskipun disini lembaga pembiayaan selaku kreditor telah memperoleh sertifikat fidusia. Namun, apabila kreditor membuat akta fidusia melalui surat kuasa membebankan fidusia di bawah tangan, maka akan membawa konsekuensi dapat tidak diperolehnya hakhak istimewa sebagaimana yang telah dijanjikan oleh undang-undang kepada kreditor pemegang sertifikat fidusia.

Pada Putusan Pengadilan Tinggi Bandung Nomor : 87/PDT/2018/PT.BDG yang menjadi contoh kajian dalam penelitian ini, diketahui bahwa akibat hukum dari digunakannya surat kuasa 
membebankan fidusia yang dibuat di bawah tangan oleh lembaga pembiayaan, sebagai dasar pembuatan akta jamina fidusia dan sertifikat jaminan fidusia, mengakibatkan sertifikat jaminan fidusia tersebut tidak sah dan tidak mempunyai kekuatan hukum. Artinya, meskipun lembaga pembiayaan selaku kreditor telah memperoleh sertifikat jaminan fidusia, namun karena lembaga pembiayaan selaku kreditor tersebut membuat akta fidusia melalui surat kuasa di bawah tangan, maka sebagai konsekuensinya apabila terjadi sengketa hukum, lembaga pembiayaan selaku kreditor tidak memperoleh hak-hak istimewa sebagaimana yang telah dijanjikan oleh undangundang.

Selanjutnya jika mengacu pada Pasal 1320 KUHPerdata, disebutkan bahwa suatu perjanjian dinyatakan sah apabila memenuhi 4 syarat, yaitu: (1). kata sepakat dari para pihak; (2) kecakapan; (3). suatu hal tertentu; dan (4). suatu sebab yang halal. Syarat pertama dan kedua dinamakan syarat subjektif, karena berkenaan dengan para subjek yang membuat perjanjian itu. Perjanjian yang dibuat tidak memenuhi syarat pertama dan kedua, maka perjanjian tersebut dapat dibatalkan (melalui pengadilan). Sedangkan syarat ketiga dan keempat dinamakan syarat objektif karena berkenaan dengan objek dalam perjanjian tersebut. Apabila perjanjian yang dibuat tidak memenuhi syarat ketiga dan keempat, maka perjanjian tersebut batal demi hukum (otomatis batal tanpa melalui pengadilan).

Demikian halnya dalam pembuatan suatu perjanjian pemberian kuasa dari pemberi fidusia kepada penerima fidusia yang berhubungan dengan pendaftaran fidusia, harus memenuhi adanya 4 persyaratan sebagai berikut:

1. Kesepakatan kedua belah pihak;

2. Kemampuan atau kecakapan melakukan perbuatan hukum;

3. Adanya suatu hal tertentu yang diperjanjikan;

4. Sebab yang halal (sesuatu yang diperjanjikan tidak bertentangan dengan ketertiban umum, kesusilaan, dan peraturan perundang-undangan yang berlaku).

Dua syarat pertama yaitu kesepakatan kedua belah pihak dan kemampuan atau kecakapan melakukan perbuatan hukum merupakan syarat subjektif, sedangkan dua syarat kedua, yaitu hal tertentu dan sebab yang halal (sesuatu yang diperjanjikan tidak bertentangan dengan ketertiban umum, kesusilaan, dan peraturan perundangundangan), merupakan syarat obyektif. Suatu perjanjian pemberian kuasa dari pemberi fidusia kepada penerima fidusia yang berhubungan dengan pendaftaran fidusia yang tidak memenuhi syarat pada nomor 1 dan 2 di atas dapat dibatalkan, sedangkan yang tidak memenuhi syarat nomor 3 dan 4 batal demi hukum. Artinya, jika suatu perjanjian pemberian kuasa tidak memenuhi syarat subjektif, maka perjanjian 
tersebut dapat dibatalkan. Sedangkan, jika suatu perjanjian pemberian kuasa tidak memenuhi syarat objektif, maka perjanjian tersebut batal demi hukum.

Dapat dibatalkan artinya salah satu pihak dapat memintakan pembatalan itu. Perjanjiannya sendiri tetap mengikat kedua belah pihak, selama tidak dibatalkan (oleh hakim) atas permintaan pihak yang berhak meminta pembatalan tadi (pihak yang tidak cakap atau pihak yang memberikan sepakatnya secara tidak bebas). Sedangkan batal demi hukum artinya adalah dari awal perjanjian itu telah batal, atau dianggap tidak pernah ada, apabila syarat objektif tidak dipenuhi. Perjanjian itu batal demi hukum, dari semula tidak pernah ada dilahirkan suatu perjanjian dan tidak pernah ada suatu perikatan. ${ }^{11}$

$$
\text { Terkait }
$$
dengan permasalahan kedua dalam penelitian ini, maka ketentuan Pasal $1320 \quad$ KUHPerdata tersebut, dapat digunakan untuk menganalisis akibat hukum terhadap sertifikat fidusia yang telah diperoleh lembaga pembiayaan, apabila pada saat pembuatan akta fidusianya didasari dengan surat kuasa membebankan fidusia di bawah tangan. Menurut Gatot Supramono, Hakim Tinggi sekaligus Wakil Ketua Pengadilan Tinggi

11 "Batalnya suatu perjanjian" (online), 25 Agustus 2004 , (http://www.hukumonline.com/ klinik/detail/cl3520/batalnya-suatuperjanjian, diakses tanggal 25 Agustus 2018).
Padang tahun 2016 menjelaskan bahwa "prinsip dalam membuat perjanjian adalah satu akta untuk satu perjanjian dan satu objek perjanjian. Prinsip ini sejalan dengan syarat sahnya perjanjian yang diatur dalam Pasal 1320 KUHPerdata salah satunya adalah hal tertentu, yang berarti objek perjanjian harus tertentu. Apabila yang dibuat para pihak adalah perjanjian jaminan, maka objeknya barang yang dijaminkan untuk sebuah utang."12

Berdasarkan uraian di atas, dapat dipahami bahwa adanya pengaturan mengenai pemberian kuasa di dalam perjanjian jaminan fidusia tidak sesuai atau bertentangan dengan syarat ketiga sahnya perjanjian yakni tentang "suatu hal tertentu". Hal ini juga ditegaskan oleh Gatot Supramono bahwa "pengaturan perjanjian pemberian kuasa seperti ini (baca: dalam perjanjian jaminan) tidak sejalan dengan prinsip membuat perjanjian dalam Pasal $1320 \quad$ KUHPerdata tentang hal tertentu, karena objek perjanjian fidusia ternyata memperjanjikan hal-hal yang di luar ruang lingkup fidusia." ${ }^{13}$ Oleh karenanya, bisa disimpulkan klausul atau pasal mengenai pemberian kuasa yang ada di dalam perjanjian jaminan fidusia bertentangan Pasal 1320 ayat (3) KUHPerdata yaitu "suatu hal

12 Gatot, Supramono, Perjanjian Utang Piutang (Jakarta: Kencana Prenada Media Group, 2013), halaman 203.

${ }^{13}$ Ibid., halaman 205. 
tertentu" sehingga batal demi hukum.

\section{PENUTUP}

\section{A. Kesimpulan}

Berdasarkan hasil penelitian dan pembahasan, peneliti dapat simpulkan beberapa hal sebagai berikut:

1. Penggunaan surat kuasa membebankan fidusia di bawah tangan sebagai dasar pembuatan akta fidusia oleh lembaga pembiayaan selama ini tidak dapat dibenarkan menurut hukum jaminan nasional. Walapun Peraturan Pemerintah Nomor 21 Tahun 2015 tidak mengaturnya, hal ini bukan berarti penggunaan surat kuasa membebankan fidusia di bawah tangan dapat dibenarkan. Hukum jaminan telah meletakan fidusia sebagai bagian dari sistem hukum jaminan kebendaan yang menganut asas tertutup dan memaksa. Oleh karena itu, ketiadaan pengaturan mengenai surat kuasa membebankan fidusia dalam Peraturan Pemerintah Nomor 21 Tahun 2015 tidak dapat begitu saja diisi oleh ketentuan perbuatan hukum yang dapat melahirkan kuasa (lastgeving) dalam Buku III KUHPerdata. Melainkan secara sistemik harusnya digunakan ketentuan hukum jaminan kebendaan yang lain untuk melengkapinya.

2. Akibat hukum yang timbul maupun diperoleh lembaga pembiayaan selaku kreditor dari pembuatan akta fidusia berdasarkan surat kuasa tersebut, akan bergantung pada keabsahan surat kuasa membebankan fidusia yang telah dibuat sebelumnya. Meskipun disini lembaga pembiayaan selaku kreditor telah memperoleh sertifikat fidusia, namun apabila kreditor membuat akta fidusia melalui surat kuasa membebankan fidusia di bawah tangan, maka akan membawa konsekuensi dapat tidak diperolehnya hakhak istimewa sebagaimana yang telah dijanjikan oleh undang-undang kepada kreditor pemegang sertifikat fidusia. Di samping itu, klausul atau pasal mengenai pemberian kuasa yang ada di dalam perjanjian jaminan fidusia bertentangan Pasal 1320 ayat (3) KUHPerdata yaitu "suatu hal tertentu" sehingga batal demi hukum.

\section{B. Saran}

Berdasarkan simpulan tersebut, maka peneliti mencoba memberikan saran sebagai berikut:

1. Bagi pemerintah, demi kepastian hukum dan demi menciptakan unifikasi hukum, pemerintah perlu menerbitkan peraturan perundangundangan yang mengatur secara tegas syarat, bentuk dan substansi surat kuasa membebankan fidusia. Dalam konteks ini, maka UndangUndang Jaminan Fidusia dan Peraturan Pemerintah Nomor 21 Tahun 2015 perlu direvisi.

2. Bagi lembaga pembiayaan, pembuatan akta fidusia atas dasar surat kuasa membebankan fidusia yang dibuat di bawah tangan adalah merupakan hal yang mengandung resiko, karena perbuatan menjaminkan adalah merupakan tindakan yang 
termasuk kategori tindakan kepemilkan, sehingga untuk meminimalisasi resiko disangkal keabsahan tanda tangan, kehadiran para pihak dan isinya, maka sebaiknya surat kuasa tersebut dibuat dalam bentuk notariil atau minimal surat kuasa tersebut dilegalisasi oleh notaris. Kekuatan pembuktian dari akta di bawah tangan yang dilegalisasi belum/tidak sesempurna akta notariil, namun ada jaminan dari pejabat umum (notaris) bahwa tanda tangan yang tertera di akta di bawah tangan tersebut benar-benar tanda tangan dari orang/pihak yang disebutkan dalam akta tersebut.

3. Bagi masyarakat, agar berhatihati dalam memberikan surat kuasa, apalagi pemberian surat kuasa dengan cara di bawah tangan untuk melakukan perbuatan hukum tertentu yang terkait dengan tindakan kepemilikan. Hal ini untuk menghindari penyalahgunaan surat kuasa oleh pihak-pihak yang tidak bertanggungjawab, oleh sebab itu sebaiknya pemberian surat kuasa tersebut dibuat dalam bentuk notariil atau minimal pemberian surat kuasa tersebut dilegalisasi oleh notaris.

\section{DAFTAR PUSTAKA}

\section{a. Buku-buku}

Gatot Supramono. Perjanjian Utang Piutang. Jakarta: Kencana Prenada Media Group, 2013.

Hartono Soerjopratiknjo. Perwakilan Berdasarkan Kehendak. Yogyakarta:
Seksi Notariat, Fakultas

Hukum, Universitas

Gadjah Mada, 1982.

Herlien Budiono. Kumpulan Tulisan

Hukum Perdata: Di

Bidang Kenotariatan

(Buku 1). Jakarta: Citra

Aditya, 2007.

J. Satrio. Hukum Jaminan, Hak-hak Jaminan Kebendaan.

Bandung: PT. Citra Aditya Bhakti, 2001.

--. Hukum Perikatan,

Perikatan yang lahir dari

Perjanjian Buku I,

Cetakan II. Bandung: PT

Citra Aditya Bhakti, 2001.

Mariam Darus Badrulzaman.

Sistem Hukum Benda

Nasional. Bandung:

Alumni,1994.

Munir Fuady. Jaminan Fidusia :

Cetakan Kedua Revisi.

Bandung: Citra Aditya

Bakti, 2003.

Hutang. Hukum Jaminan
Erlangga, 2003. Jakarta:

Rachmad Setiawan. Hukum

Perwakilan dan Kuasa,

Suatu Perbandingan

Hukum Indonesia dan

Hukum Belanda Saat Ini.

Jakarta: Tatanusa, 2005.

Ridwan Khairandy. Hukum Kontrak Indonesia Dalam

Perspektif Perbandingan.

Yogyakarta:UII Press, 2013.

Sudikno Mertokusumo. Penemuan Hukum Sebuah

Pengantar, Edisi Revisi. Yogyakarta:Cahaya Atma Pustaka, 2004.

\section{b. Peraturan Perundang-undangan}

Kitab Undang-undang Hukum Perdata (KUHPerdata) 
yang termuat dalam Buku II KUHPerdata.

Undang-Undang Nomor 42 Tahun 1999 tentang Jaminan Fidusia.

Peraturan Pemerintah Nomor 21 Tahun 2015 tentang Tata Cara Pendaftaran Jaminan Fidusia Dan Biaya Pembuatan Akta Jaminan Fidusia.

c. Website

"Batalnya suatu perjanjian"
(online), 25 Agustus
2004,
(http://www.hukumonline.
com/
klinik/detail/cl3520/batalny
a-suatu-perjanjian,
diakses tanggal 25
Agustus 2018).

